Original Research Paper

\title{
Recent Progress in Self-Cleaning Materials with Different Suitable Applications
}

\author{
${ }^{1}$ Siavash Hosseinpour Chermahini, ${ }^{2}$ Kaveh Ostad-Ali-Askari, ${ }^{3}$ Saeid Eslamian and ${ }^{4}$ Vijay P. Singh \\ ${ }^{I}$ Department of Mechanical Engineering, Universiti Teknologi Petronas (UTP), \\ DarulRizvan, Bandar Seri Iskandar, 32610 Perak, Malaysia \\ ${ }^{2}$ Department of Civil Engineering, Isfahan (Khorasgan) Branch, Islamic Azad University, Isfahan, Iran \\ ${ }^{3}$ Full Professor, Department of Water Engineering, Isfahan University of Technology, Isfahan, Iran \\ ${ }^{4}$ Full Professor, Department of Biological and Agricultural Engineering and Zachry, \\ Department of Civil Engineering, Texas A and M University, \\ 321 Scoates Hall, 2117 TAMU, College Station, Texas 77843-2117, U.S.A
}

Article history

Received: 26-02-2018

Revised: 05-04-2018

Accepted: 24-04-2018

Corresponding Author:

Kaveh Ostad-Ali-Askari

Department of Civil

Engineering, Isfahan

(Khorasgan) Branch, Islamic

Azad University, Isfahan, Iran Email:

koa.askari@khuisf.ac.ir

\begin{abstract}
Self-cleaning properties have received significant attention for the importance of their potential. Coatings at Nano-scales offer possibilities of using materials for self-cleaning surfaces. Recent efforts have begun to focus on the kinds of materials including metals, semiconductors and polymers. Such materials can have enormous potential in only a few applications. Moreover, the production of these materials requires high costs with low photo activity. In this regard, $\mathrm{TiO}_{2}$ and its derived materials have shown acceptable and effective suggestions for this application. Moreover, the mechanism of self-cleaning has been explained by the effect of hydrophilic and hydrophobic. Hydrophilic and hydrophobic can have many applications in different areas like water purification, microfluidics and photovoltaic. In this review, the application of self-cleaning in solar cells and environment as well as $\mathrm{TiO}_{2}$ derived materials and their applications in water management have been briefly illustrated. In addition, it has been explained that a huge number of self-cleaning materials, applications and improvement in utilities have been essential. In short, we have conducted a comprehensive review of the new approach and to mention numerous materials with hydrophobic and hydrophilic properties would be promising for most environmental concerns. Bio-inspired surface respond in nature through hydrophobic (Cicada Wing, Butterfly Wing, Lotus Leaf, Rice Leaf) and hydrophilic (Fish Scale, Snail Shell, Shark Skin) properties was divided in 4 and 3 respectively. Anti reflective coatings with self-cleaning properties have drowned considerable attention for both their basic appearances and vast applied usages. Antireflective coatings with self-cleaning properties have been considered because of their fascinating features and vast diversity of empirical uses.
\end{abstract}

Keywords: Self-cleaning, $\mathrm{TiO}_{2}$, Hydrophobic

\section{Introduction}

Self-cleaning materials with different suitable wettability for different applications have been the main concern in solar energy area (Banerjee et al., 2015). Due to numerous applications, various materials have been the center of researchers' attention (Andrews et al., 2013). Those are materials used in house furniture and glasses, or out of the house like solar panels in roof (Liu et al., 2014a). Surfaces coated with self-cleaning material can be cleaned by rain, for example, even though waxy substances such as insect bodies or leave parts may cling unto the surface (Fillion et al., 2014).

Self-cleaning surfaces are either hydrophilic or hydrophobic (Oberli et al., 2014). When the surface is hydrophilic, water spreads over it, washing away the contaminants. When the surface is hydrophobic, water particles roll over into droplets, removing, in the process, dust and washing away the contaminants (Zhang et al., 2012). Some reviewers have mentioned 
the photocatalytic activity of titanium dioxide (Nishimoto and Bhushan, 2013). $\mathrm{TiO}_{2}$ has been studied for its potential use in water purification and air and water decontamination. $\mathrm{TiO}_{2}$ is being considered in relation to applications in antireflection materials, biosensors (Bixler et al., 2014), photoelectron catalysis (Zhao et al., 2014) and solar cells (Liu et al., 2013a). With regards to photocatalytic properties, $\mathrm{TiO}_{2}$ composites are generally considered the best for their physical and chemical characteristics. $\mathrm{TiO}_{2}$ films can provide UV protection, deodorizing effect (Ragesh et al., 2014), antibacterial and self-cleaning functions (Ueda and Levkin, 2013) when used as coating material. The use of $\mathrm{TiO}_{2}$ maximizes photocatalytic effect; however, $\mathrm{TiO}_{2}$-based materials used as photo catalysts are difficult and costly to recycle (Tian et al., 2013a). We have introduced several hydrophilic and hydrophobic $\mathrm{TiO}_{2}-$ based materials and discussed combined self-cleaning and hydrophobic or hydrophilic properties with photocatalytic activity. Self-cleaning coatings for materials such as glass, cement and paint have also been discussed with the iteration that a material used as a selfcleaning coating should have two characteristics; first, not being easily oxidized and second, help remove dust and particles when washed by rain or blown by the wind. There are other considerations, such as reflectivity and transparency. Polysiloxane and organosilicons are suitable candidates for making coating materials when all of these requirements are taken into account. We have also discussed $\mathrm{TiO}_{2}$ compounds with high adhesive strength and high surface effect. The get bigger profits in self-clean coatings contains to their low preservation value, high persistence and great possible usages. So, coatings, for sample, may propose beneficial persistence against fouling, icing, corrosion. Hybrid surfaces containing of a micro pillar discipline of hydrophobic and hydrophilic places were planed and created to realize the effects of their unique surface morphology and chemistry on droplet concentration condensation. Droplet impact tests have disclosed that hybrid surfaces depict high contact angles, which is feature of merely hydrophobic surfaces.

\section{Hydrophilic Properties}

There is a photocatalytic phenomenon in hydrophilic surfaces, whereby the presence of light will cause the decomposition of dust and other contaminants (Song and Mano, 2013). Currently, $\mathrm{TiO}_{2}$ and its photocatalytic derivatives are considered important substances with a high potential. $\mathrm{TiO}_{2}$ is a chemically and physically stable material that is not only easily available. Furthermore and it has low toxicity, low cost and high photo activity compared to materials currently in use (Lai et al., 2013). When it comes to the use of $\mathrm{TiO}_{2}$ as a self-cleaning material, it is restricted by its limited absorption of UV light. This is because UV light is only $3-5 \%$ of the solar range. Hence, for outdoor applications, the use of pure
$\mathrm{TiO}_{2}$ during the fabrication of self-cleaning materials, like glass and tiles, is a limiting factor due to the low availability of UV light. Several strategies for increasing the efficacy of utilizing the visible sector of the solar spectrum have been suggested (Kisch, 2013). The hydrophilic characteristic of $\mathrm{TiO}_{2}$ was reported by Wang et al. (2014a). Their research made note of the fact that water would spread on $\mathrm{TiO}_{2}$ surfaces that were irradiated by UV light. It was found that the UV irradiation reduced the contact angle between the surface and the water to $0^{\circ}$. This same thing happened when oily liquids like hexadecane were tested on the surface (Keane et al., 2014). There are several advantages of using $\mathrm{TiO}_{2}$ in self-cleaning coatings. These advantages include high transparency of $\mathrm{TiO}_{2}$ thin films, high photocatalytic activity and hydrophilic properties that occur due to UVirradiation. Single layers and multiple layers of $\mathrm{TiO}_{2}$ were coated on materials like glass through using a layer-by-layer technique, thus creating self-cleaning materials (Fisher et al., 2013). The ability of these photocatalytic sheets to degrade chemicals was tested on methylene blue. A cost-effective technique for use in photovoltaic cells has been explored recently. The technique was deemed suitable for use in fabricating photocatalytic, hydrophilic and high transparency $\mathrm{TiO}_{2}$ films (Banerjee et al., 2014). Under the microscope, it was observed that UV irradiation caused the change in contact angle. UV irradiation causes changes in the $\mathrm{TiO}_{2}$ solid-liquid boundaries on the surface $(\mathrm{Qu}$ and Duan, 2013). Each $\mathrm{TiO}_{2}$ molecule has six positions, five of which are filled with $\mathrm{Ti}$ atoms, with the last position occupied by $\mathrm{H}_{2} \mathrm{O}$ or $\mathrm{OH}^{-}$group. Irradiation with UV light causes an oxygen bridging area to form on the surface by converting $\mathrm{Ti}^{4+}$ ions to $\mathrm{Ti}^{3+}$ (Zhao et al., 2013). Microscopic observation of $\mathrm{TiO}_{2}$ crystals revealed that there were hydrophilic and Oleopholic parts on the $\mathrm{TiO}_{2}$ surface that allowed for the formation of microscopic flow channels for oil and water (Sakai et al., 2003). According to previous research, $\mathrm{TiO}_{2}$ coated materials with hydrophilic properties that were stored in the dark for two days showed a decrease in hydrophilic properties. This was due to the slow substitution of oxygen in the air with water. It is possible to recover the hydrophilic properties of the surface by exposing it to UV light again. The experiments showed that $\mathrm{TiO}_{2}$ has convertible hydrophilic properties and that hydrophilicoleo phobic properties can be induced on the surface by UV irradiation (Emeline et al., 2013). Highly interrelated hydrophilic polymers were collected through the polymerization of (paraffin-oil)-in-water emulsion samples using interior phases below 74 vol\%. Moisture adsorption, water contact angle, swelling test, water vapor transmission and mechanical tests were executed to appraise the hydrophilicityhydrophobicity. the Titanium (Ti) surfaces with various construction, combination, crystal Fig. 1 and grain size are disposed by micro arc oxidation and 
thermal treatment and then their hydrophilicity and surface roughness are considered. The empirical results show that there is no essential correlation between hydrophilicity and surface roughness.

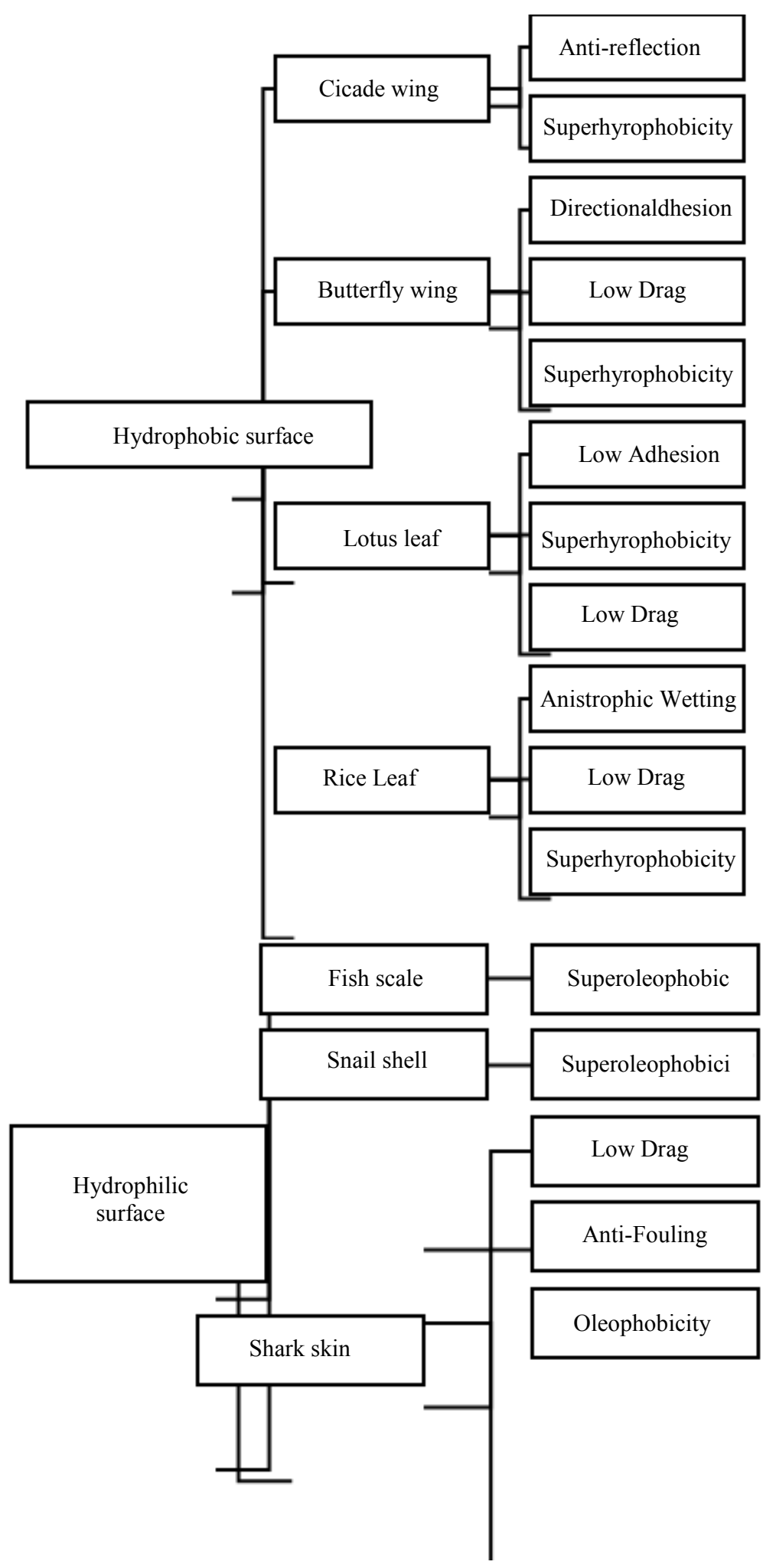

Fig. 1: Bio-inspired surface respond in nature through hydrophobic and hydrophilic properties 


\section{Hydrophobic Properties}

A hydrophobic surface can be fabricated by controlling chemical combinations and monitoring the structural properties of solid surfaces. Unlike hydrophilic materials, there are not as many examples of hydrophobic surfaces (Emeline et al., 2013). Hydrophobic surfaces have several self-cleaning advantages when compared to hydrophilic surfaces. These advantages include the reduced potential adhesion of bacterial activities (Li et al., 2015a) and extra cleaning activity (Zhang et al., 2015a). Functionalizing $\mathrm{TiO}_{2}$ through the modification of surface morphology has an added benefit of increasing smoothness and lowering free energy on the surface. The aim of creating hydrophobic surface coating is usually to prevent hydrophilic $\mathrm{TiO}_{2}$ conversion through irradiation when it displays photocatalytic and hydrophobic characteristics. The transparency of hydrophobic films were investigated by through calcination of a mixture of titanium acetylacetonate and aluminum acetylacetonate, then coated with fluoroalkylsilane (Zhang et al., 2015a). The films were characterized according to their porous and smooth surface where the roughness was correlated to $\mathrm{TiO}_{2}$ concentration. This particular experiment showed the constant hydrophobicity of the film and photocatalytic properties of stains for up to $1800 \mathrm{~h}$. The photocatalytic potential of $\mathrm{TiO}_{2}$, in addition to its photo induced amphiphilic property can be explained by the self-cleaning action of the hydrophobic film (Liu et al., 2013b; Katsanaki et al., 2013; Pelaez et al., 2012). There was an increase in the Ti/oxygen volume and consequently, the value of hydroxyl group due to exposure to UV light (Hamilton et al., 2014; Weng and Huang, 2013). A group of scientists carried out a survey to test the self-cleaning ability of some materials by using graphite powder on the surface. The results showed that the graphite was adsorbed easily by the surface through the water on the hydrophobic surface. As a result, the graphite slid off the surface (Kitano et al., 2013; Reszczyńska et al., 2015). One simple and applicable fabrication method can give the surface the ability to repair and introduce a new generation of hydrophobic surfaces. This phenomenon is important because it causes less mechanical damage. It is also beneficial when used in self-cleaning materials. A hydrophilic surface was successfully created by irradiating the photocatalytic hydrophobic surface with UV light. This was due to the oxygen that was gathered through heating. However, this was only possible provided that the film - a hydrophobic surface - was stored outdoors for 4 weeks in high humidity conditions i.e., $>90 \%$. The increased hydrophobicity between the hybrids of inorganicorganic films was attributed to the chains of the hydrocarbon throughout the hybrid film (Wu et al., 2013a). Super hydrophobic surfaces for self-cleaning utilizations often toil mechanical inconsistency and do not work excellent after abrasion/scratching. Coverage of $\mathrm{TiO}_{2}$ nanoparticles to the formulation displays expand addition in water contact angle owing to the structural betterment with hierarchical surface roughness. Mechanical consistency and persistence of the coatings has been attained by using a mercantile sticky to bond the super hydrophobic "paint" to different layers, considering of super hydrophobic materials inspired by nature has drawn major scientific interest in last decades. A main compete of using the superhydrophobic surfaces for the selfcleaning coatings production is their modified proficiency in different atmospheric conditions, e.g., UV light. Tribological and hydrophobic properties of the varied surfaces were associated with their chemical structures. After accelerated UV presentation, no considerable variations in the chemical structure, hydrophobic and tribological features of the modified surfaces were detected. Hydrophobic efficacy was supported in UV light what can be undertaking in efficient self-cleaning coatings receiving. Zinc Oxide $(\mathrm{ZnO})$ Nano rods were combined at room temperature on potassium permanganate operated silicon and glass layer by simple chemical procedure using zinc acetate as pioneer. The surface energy of the as produced pure and coated models was computed by evaluating the contact angle of two several liquids. Also, even after UV irradiation the contact angle stay same unlike the state for the uncoated model where the contact angle gets reduced importantly after UV irradiation. Applying the new hydrophobic sample, the prediction error of contact angle can be less than $3 \%$ contrasted with the measured one.

\section{Antibacterial Activities}

Recently, materials with photocatalytic properties like $\mathrm{TiO}_{2}$ derivatives have garnered attention from researchers. This is due to the fact that materials like $\mathrm{TiO}_{2}$ have a potential use as self-cleaning antibacterial material (Niu et al., 2013; Feng et al., 2013; Afzal et al., 2013; Wu et al., 2013b; Xiao et al., 2014; Etacheri et al., 2013). Investigated the self-cleaning properties of $\mathrm{TiO}_{2}$ and found films that contained $\mathrm{TiO}_{2}$ had photocatalytic activity with antibacterial effects that were caused by irradiation by UV light (Patrocinio et al., 2014). Nanocomposites like $\mathrm{CuxO} / \mathrm{TiO}_{2}$ had been used to aid visible light absorbance in indoor conditions. The $\mathrm{CuxO}$ used in the nanocomposites were a mixture of $\mathrm{Cu}$ (II) and $\mathrm{Cu}$ (I) (Tian et al., 2013b; Wang, 2014). 
Table 1: Hydrophilic and hydrophobic characteristics of $\mathrm{TiO}_{2}$

\begin{tabular}{|c|c|c|}
\hline Hydrophilic & Hydrophobic & Reference \\
\hline Potential adhesion of bacterial activities & $\begin{array}{l}\text { Decrease the potential adhesion } \\
\text { of bacterial activities }\end{array}$ & Li et al. (2015a) \\
\hline Cleaning activity Potential & Extra cleaning activity Potential & Zhang et al. (2015a) \\
\hline $\begin{array}{l}\text { High quality of hydrophilic due to } \\
\text { UV-irradiation }\end{array}$ & - & Fisher et al. (2013) \\
\hline Water would spread on $\mathrm{TiO}_{2}$ surfaces & Water would slide off $\mathrm{TiO}_{2}$ surfaces & Kisch (2013) \\
\hline- & Graphite adsorption by hydrophobic surface & $\begin{array}{l}\text { Kitano et al. (2013; } \\
\text { Reszczyńska et al., 2015) }\end{array}$ \\
\hline Contact angle between $0^{\circ}$ and $90^{\circ}$ & Contact angle more than $90^{\circ}$ & Kisch (2013) \\
\hline- & $\begin{array}{l}\text { Photocatalytic potential of } \\
\mathrm{TiO}_{2} \text { and its photo induced } \\
\text { amphiphilic property }\end{array}$ & $\begin{array}{l}\text { Liu et al. (2013b; } \\
\text { Katsanaki et al., 2013; } \\
\text { Pelaez et al., 2012) }\end{array}$ \\
\hline
\end{tabular}

The visible light absorption of $\mathrm{TiO}_{2}$ and photocatalytic oxidation of volatile compounds increased when in the presence of $\mathrm{Cu}$ (II). In the absence of light, $\mathrm{Cu}$ (I) had antimicrobial properties (Fateh et al., 2014). Photocatalysts were used to perform photocatalytic disinfection of Aspergillus niger, Staphylococcus. Aureus, Escherichia coli, Candida. Albicans and Enterococcus faecalis. The order of inactivation was found to be as follows: $E$. coli $>S$. aureus $>E$. faecalis $>C$. albicans $>A$. niger (Karimi et al., 2014a; Zhu et al., 2014; Yao and He, 2014; Xu et al., 2013a). The fabricated surface with $\mathrm{TiO}_{2}$ followed by $\mathrm{Ag}$ nanoparticles showed a high antibacterial potential against E. coli (Kapridaki et al., 2014). Antibacterial characteristics can be retrained for a long time by inserting $\mathrm{Ag}$ nanoparticles between $\mathrm{TiO}_{2}$ nanotubes and ammonium salt in Table 1. According to previous research, nanocomposites that exist in this combination have a high potential for biocompatibility and can retain antibacterial characteristics for a long time. The ammonium salts in the surface of the coating causes a decrease in the release of $\mathrm{Ag}$ from the nanocomposites (Lien et al., 2013; Erdural et al., 2014). Electrochemical anodization was used to test the antibacterial properties of titanium nanotubes on $E$. coli and $S$. aureus. The investigation revealed that $E$. coli $(97.5 \%)$ and $S$. aureus $(99.9 \%)$ were successfully disinfected by the nanotube materials after the application of UV irradiation. Two characteristics of surface structural morphology and also physiochemical properties of titanium materials play a significant duty in anti-bacterial activity (Mokhtarimehr et al., 2015). The structure of $\mathrm{AgI} / \mathrm{TiO}_{2}$ has shown potential as it has efficient photocatalytic activity with regards to antibacterial cases and organic pollutants (Wang et al., 2014a; Pakdel et al., 2013; Pakdel and Daoud, 2013; Li and He, 2013). The active visible light self-cleaning of cotton fibers coated with $\mathrm{AgI}$ and $\mathrm{TiO}_{2}$ shows a more efficient degradation of methyl orange after visible light irradiation, as compared to the self-cleaning activity of cotton fibres coated with $\mathrm{TiO}_{2}$ alone (Nakata et al., 2014). Silver nanoparticles have been applied on the surface of $\mathrm{TiO}_{2}$ nanoarrays in order to combine photocatalytic self-cleaning surfaces with active surface detection (Guldin et al., 2013; Yadav et al., 2014). There is a suggested antibacterial activity mechanism for $\mathrm{TiO}_{2}$ that when the cell wall and cell membrane of bacterial cells are destroyed, it means that $\mathrm{TiO}_{2}$ is irradiated (Li et al., 2013a).

\section{Photo-Controlled Wetting}

There has been a novel application regarding photocontrolled wetting applied for bio-materials and some other materials like ceramic which is called reversible photo-response surface. This technique, because of its different applications, has attracted researchers' attention that focused on controlled wetting properties (Wang et al., 2014b; Li et al., 2013b; Xu et al., 2013b; Zhang et al., 2013a; Crick et al., 2012). This is a 'smart coatings' which has the ability to switch from time to time to hydrophilic and hydrophobic surfaces by light irradiating under specific wavelength (Wooh et al., 2014; Nandan et al., 2015). The specific characteristics of this kind of materials have various applications in different areas that can be such as controlled drug delivery, membranes and sensors and finally surface coatings (Xie et al., 2014; Xu et al., 2013c; Mills et al., 2012; Yang et al., 2002; Sawai et al., 2013). In this regard-, there are some factors with higher importance in case of leading the nature of wetting which includes degree of the surface polarity, morphology and roughness of the surface (Wang and Guo, 2014; Gao et al., 2014a). One researcher called Li, together with his colleagues, worked on providing a new micro-Nano silica/titanium thin-film combination through Nano-spheres of $\mathrm{TiO}_{2}$ and $\mathrm{SiO}_{2}$ and a kind of water-resistant substances i.e., Aquapel. This new micro combination of $\mathrm{TiO}_{2}-\mathrm{SiO}_{2}$ has the potential of diverse wettability (Gao et al., 2014b). Moreover, this composite has performed a pattern which angles in 
water significantly and dependent on the microscopic roughness of the surface (Gao et al., 2014b). Since this composite of $\mathrm{TiO}_{2}-\mathrm{SiO}_{2}$ has different ratio in size, it has some effects on their properties (Gao et al., 2014b; André et al., 2013; Zang et al., 2014). In another survey, illustrate that reducing of hydrophilicity potential can be due to surface restructuring titanium during the irradiation process (Balachandran et al., 2014).

\section{Self-Cleaning Materials}

Besides all $\mathrm{TiO}_{2}$ derives for self-cleaning purpose as explained before, there are some metal oxide materials like $\mathrm{SnO}_{2}$ and $\mathrm{ZnO}$, which have the potential of photocatalytic activity (Mills et al., 2013). These n-type metals such as $\mathrm{SnO}_{2}$ show- the characteristics of switchable hydrophobicity and hydrophilicity before and after UV irradiation (Mills et al., 2014a). The hydrophobic and hydrophilic conversion has been credited from surface roughness whereas oxygen and hydroxyl produced due to UV irradiation. $\mathrm{SnO}_{2}$ films fabrication on glass have been achieved by spermine functionalization (Mills et al., 2014b). The $\mathrm{SnO}_{2}$ with cooperation of superoxide radicals and sunlight lead to degradation of pathogens and organic dyes. Photo induced hydrophilicity characteristics of $\mathrm{SnO}_{2}$ films together with photocatalytic properties can be used for coatings with properties of antifouling. Pan and his colleagues surveyed the experiment of fabrication $\mathrm{SnO}_{2}$ hydrophobicity base on morphological surface roughness (Bateman et al., 2012). The microchannel created on the surface led to air entrance into the channels and as a result, prevention from water penetration. This switchable wettability structure with the potential of changing via UV irradiation can be useful for industrial coatings regarding self-cleaning applications. Some researchers with the leadership of Sun found that $\mathrm{ZnO}$ films showed a conversion of photo-induced hydrophilic (Radeka et al., 2014). This phenomenon has been credited to surface defects like $\mathrm{TiO}_{2}$ against UV following by adsorption of water. Another researcher called Plasmon surveyed the visible part of light absorbed by the hybrid of $\mathrm{Ag}-\mathrm{ZnO}$ and increased photocatalytic activity because of specific combined structure (Ke et al., 2014). The UV part persuaded photocatalytic active Nano arrays which potentially could be applied for self-cleaning in Fig. 2. (Midtdal and Jelle, 2013; Lu et al., 2015).

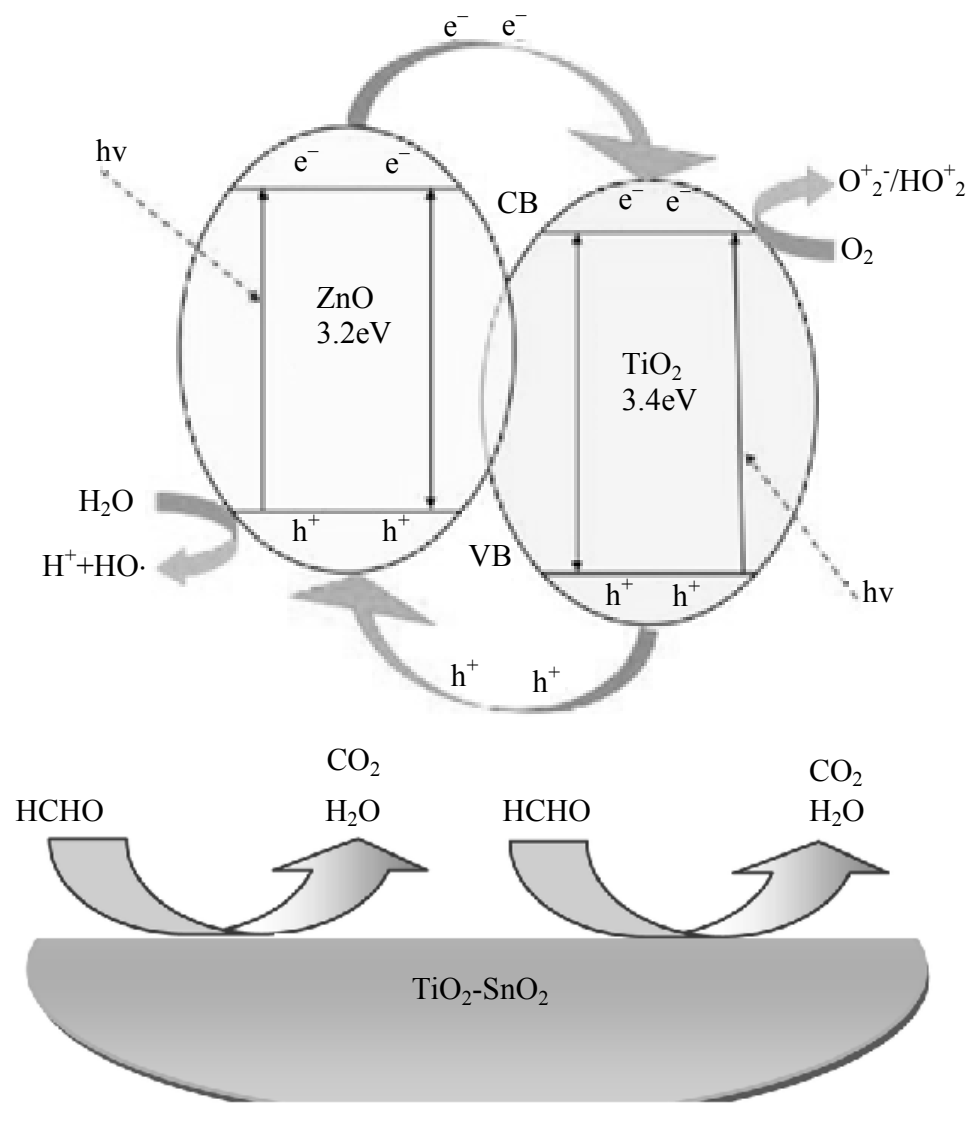

Fig. 2: Schematic image of metal oxide material $\left(\mathrm{ZnO}\right.$ and $\left.\mathrm{SnO}_{2}\right)$ with photocatalytic properties 


\section{Commercial Applications}

Large scale commercially $\mathrm{TiO}_{2}$ photo induced hydrophilic conversion for various applications such as cement, glass, paints and tiles were achieved to develop self-cleaning and anti-fogging. The application of $\mathrm{TiO}_{2}$ photo catalysts in the glass of windows and tiles has been used in buildings to present the materials with the potential of photocatalytic self-cleaning in buildings construction (Spasiano et al., 2015; Murugan et al., 2013; Zhang et al., 2013b; Radetić, 2013). This modification in materials can be accomplished by solar irradiation leading to the photo catalysis process. Selfcleaning glass would be practical through Pilkington glass which involves a nanocrystal line film from $\mathrm{TiO}_{2}$ with $15 \mathrm{~nm}$ thickness on the surface of glass (Galkina et al., 2014). This active glass is one of the best products in self-cleaning applications and has recently been used in many different buildings in commercial and private all around the world. have investigated this technique as a suitable choice in case of semiconductor photo catalysis (Pasqui and Barbucci, 2014; Karimi et al., 2014b; Montazer et al., 2012). This potential has been measured in order to confirm the ability of stearic acid degradable. Moreover, there are some beneficial matters in case of active potential applicable in selfcleaning which are optimum absorption of solar radiation, low reflectance visible light (7\%) and acceptable transmittance. Nowadays, few self-cleaning window glasses like Bio-clean TM, Sun-clean TM and Radiance TiTM have been commercially added to the market. TOTO Ltd. a Japanese producer, introduces a new technology to the market that is super hydrophilicity photo induced glass that through sunlight, breaks down all pollutants in smaller sizes to be washed by rain/water. This technology has been used by TOTO Ltd. in building construction as paint and coat materials, not only indoor but also outdoor usage. These products are produced through spraying $\mathrm{TiO}_{2}$ on the glass then tempered at $600-800^{\circ} \mathrm{C}$ in order to highly attach to the surfaces (Rehan et al., 2013; Afzal et al., 2014; Kim et al., 2016; Nawaz et al., 2015). Using this high temperature leads to high stability of $\mathrm{TiO}_{2}$ which is possible to develop self-cleaning materials use in building. Recently, scientists by using a suspension from ethanol coated by $\mathrm{TiO}_{2}$ have made a combination i.e., perfluorooctyltriethoxysilane (fluoroalkylsilane) $\left(\mathrm{C}_{14} \mathrm{H}_{19} \mathrm{~F}_{13} \mathrm{O}_{3} \mathrm{Si}\right)$ which has the potential to be used for hard and soft materials as well. This kind of coatings has the potential to be used on paper, steel, clothes and glass in case of various applications. In this system, drops of water would be gathered without any effect on material (Kim et al., 2016; Sharker et al., 2015; Lee et al., 2014; Nam et al., 2013). An example for self-cleaning glass can be pointed to the National Opera Hall in China (Darmanin and Guittard, 2015). Also, in the case of white cement, can be bolded regarding to Dives in Misericordia Church in Rome (Liu et al., 2014b) and for Roof can be pointed to Cricket Stadium in Dubai Sports City (Murakami et al., 2014). There is a research that shows that by covering with active concrete $15 \%$ of ceilings in city of Milan, the pollution would be decreased up to 50\% (Miljkovic et al., 2013; Zhang et al., 2015b). Another company named Heidelberg Cement has produced TioCemTM, which is another air pollution reducer in case of self-cleaning cement (Hancock et al., 2012; Vorobyev and Guo, 2015; Long et al., 2015). Also, in Japan the tiles made of self-cleaning material for using in windows and roof from company Ecofriendly are used widely. On the other hand, antifogging characteristics of self-cleaning coatings have been used in automobile companies to produce clean mirrors and headlights (Yong et al., 2013). $\mathrm{TiO}_{2}$ films have been improved through the application of $\mathrm{Ni}^{2+}$ and $\mathrm{Fe}^{3+}$ to produce self-cleaning active materials in buildings (George et al., 2014; Yong et al., 2014; 2015). Antimicrobial activity of $\mathrm{TiO}_{2}$ has a huge potential in the construction of building materials for both indoor and outdoor applications (Lu et al., 2015; $\mathrm{Li}$ et al., 2015b; Dunderdale et al., 2015). Antimicrobial activity of $\mathrm{TiO}_{2}$ is very critical due to their applications in food industries and medical science to preserve food and drug from contamination by microbes. There are few companies that use this technique in their products which are Biocera TOTO and Karpery. They have produced films on ceramics that function as an antimicrobial agent (Shi et al., 2015). In this case, the thing which is important is the product with the characteristics of antimicrobial activity and deodorizing property in Table 2. Also, another product is cotton textile plus $\mathrm{TiO}_{2}$ nanoparticles (Shi et al., 2014a; Lochovsky et al., 2012; Dai et al., 2015; Kamei et al., 2014; Lv et al., 2014). In this case, the mechanical properties of cotton textile have been improved through $\mathrm{TiO}_{2}$ coating (Shi et al., 2014b) and antibacterial properties besides stain removal (Zhou et al., 2015; Lei et al., 2014). The effects of self-cleaning and Photocatalytic of textile were developed through soaking the fibers in multiwall carbon nanotubes and $\mathrm{TiO}_{2}$ composition and using succinic acid as a parameter to link them (Wang et al., 2013; Yao et al., 2011; Li et al., 2015c). Antimicrobial, self-cleaning and UV protection characteristics were achieved through the combination of polyester with $\mathrm{TiO}_{2}$ and $\mathrm{Ag}$ nanoparticles (Cheng et al., 2014). Also, Polyester which is coated with a combination of $\mathrm{AgI} / \mathrm{AgCl} / \mathrm{TiO}_{2}$ has increased antimicrobial properties against $E$. coli and the efficiency of methylene blue (Lei et al., 2014; Gurav et al., 2014). Materials with keratin base have been applied a lot in substances such as tires and textiles because of biodegradability (Raza et al., 2015; Wang et al., 2015; Manabe et al., 2014; Gurav et al., 2015; Shang and Zhou, 2015). 
Table 2: $\mathrm{TiO}_{2}$ photo-induced hydrophilic conversion for various applications

\begin{tabular}{|c|c|c|c|}
\hline Substrate & Formulation & Application & Reference \\
\hline Glass & Glass $+\mathrm{TiO}_{2}$ with $600-800^{\circ} \mathrm{C}$ & $\begin{array}{l}\text { Windows, tunnel, road lights } \\
\text { and vehicles }\end{array}$ & $\begin{array}{l}\text { Sharker et al. (2015; } \\
\text { Lee } \text { et al., 2014; } \\
\text { Nam et al., 2013) }\end{array}$ \\
\hline Plastic & Polyester coated with $\mathrm{gI} / \mathrm{AgCl} / \mathrm{TiO}_{2}$ & Buildings and Automotive Industries & Cheng et al. (2014) \\
\hline Tile/Cement & Cement $+\mathrm{TiO}_{2}$ & Building roof, Floor and walls & Liu et al. (2014b) \\
\hline Cotton/ Fiber/Textile & $\mathrm{MWCNT}+\mathrm{TiO}_{2}$ & $\begin{array}{l}\text { Medical devices, furniture and house } \\
\text { hold appliances }\end{array}$ & $\begin{array}{l}\text { Wang et al. }(2013 \text {; } \\
\text { Yao et al., 2011; } \\
\text { Li et al., 2015c) }\end{array}$ \\
\hline
\end{tabular}

\section{Conclusion}

This article focused on giving an overview based on photocatalytic self-cleaning materials from $\mathrm{TiO}_{2}$ and derives and considering wettability characteristics. All of the materials, which have been explained in detail, have a specific importance in environmental pollution that can be used in various solutions, such as antireflective coatings, antifogging and antibacterial. Some models, such as cement, cotton and automotive cases, have been presented in detail to realize the mechanism of hydrophilicity activity upon UV irradiation. This part of light produces changes in $\mathrm{TiO}_{2}$ surface. Photo-controlled convertible wetting characteristics recently have attracted scientist's attention. Moreover, morphology and surface roughness have been reported as the most important factors of the wetting. Several techniques, like condensation using Nano- hetero-junctions, composites and metals have been illustrated through the photocatalytic activity which could improve self-cleaning. Although, it is important to note that comparing the self-cleaning activity from different materials and sources, because of different intensities, time of irradiation etc., is quite challenging. However, any adaptations that increase the surface roughness would be recommended in case of self-cleaning activity. The application of hetero structure materials to increase self-cleaning activity looks to be an effective trend in this case.

\section{Acknowledgement}

This work was supported by Yayasan University Technologi PETRONAS (YUTP) grant with grant number: 0153-AA-A96.

\section{Conflict of interest}

The authors confirm that there are no conflicts of interest.

\section{Authors Contributions}

All authors contributed to design the study, write and revise the manuscript.

\section{Ethics}

This study was approved by Mechanical Engineering Department, Universiti Teknologi PETRONAS (UTP), DarulRizvan, Bandar Seri Iskandar, 32610 Perak, Malaysia.

\section{Recommendation}

However, a few more studies need to be performed to realize the structural relationships between materials used and the structure-wettability design of them. Common competes faced in feasible usages and the propensity of future progress are introduced and considered to simplify a global comprehension of self-cleaning coatings.

\section{References}

Afzal, S., W.A. Daoud and S.J. Langford, 2013. Photos table self-cleaning cotton by a copper(II) porphyrin $\mathrm{TiO}_{2}$ visible-light photocatalytic system. ACS Applied Mater. Interfaces, 5: 4753-4759.

DOI: $10.1021 / \mathrm{am} 400002 \mathrm{k}$

Afzal, S., W.A. Daoud and S.J. Langford, 2014. Super hydrophobic and photocatalytic self-cleaning cotton. J. Mater. Chem. A, 2: 18005-18011. DOI: $10.1039 / \mathrm{C} 4 \mathrm{TA} 02764 \mathrm{G}$

André, R., N. Filipe, M.N. Tahir, B. Rüdiger and T. Wolfgang, 2013. Self-cleaning antimicrobial surfaces by bio-enabled growth of $\mathrm{SnO}_{2}$ coatings on glass. Nanoscale, 5: 3447-3456. DOI: $10.1039 / \mathrm{C} 3$ NR00007A

Andrews, R.W., A. Pollard and J.M. Pearce, 2013. A new method to determine the effects of hydrodynamic surface coatings on the snow shedding effectiveness of solar photovoltaic modules. Solar Energy Mater. Solar Cells, 113: 71-78. DOI: 10.1016/j.solmat.2013.01.032

Balachandran, S., P. Natarajan, T. Kuppulingam, M. Manickavachagam and S. Mika et al., 2014. Facile construction of heterostructured $\mathrm{BiVO}_{4}-\mathrm{ZnO}$ and its dual application of greater solar photocatalytic activity and self-cleaning property. Industrial Eng. Chem. Res., 53: 8346-8356. DOI: $10.1021 / \mathrm{ie} 404287 \mathrm{~m}$ 
Banerjee, S., C.P. Suresh, F. Polycarpos, E.O.S. Kevin and A.B. John, 2014. New insights into the mechanism of visible light photo-catalysis. J. Phys. Chem. Lett., 5: 2543-2554. DOI: 10.1021/jz501030x

Banerjee, S., D.D. Dionysiou and S.C. Pillai, 2015. Selfcleaning applications of $\mathrm{TiO}_{2}$ by photo-induced hydrophilicity and photo-catalysis. Applied Catalysis B: Environ., 176: 396-428. DOI: $10.1016 /$ j.apcatb.2015.03.058

Bateman, R.J., X. Chengjie, L.S.B. Tammie, M.F. Anne and G. Alison et al., 2012. Clinical and biomarker changes in dominantly inherited Alzheimer's disease. New England J. Med., 367: 795-804. DOI: 10.1056/NEJMoa1202753

Bixler, G.D., T. Andrew, B. Bharat and C.L. Stephen, 2014. Anti-fouling properties of microstructure surfaces bio-inspired by rice leaves and butterfly wings. J. colloid interface sci., 419: 114-133.

DOI: $10.1016 /$ j.jcis.2013.12.019

Cheng, S., L. Xinling, Y. Shan, L. Hongjie and G. Yanfeng, 2014. $\mathrm{SiO}_{2} / \mathrm{TiO}_{2}$ composite aerogels: Preparation via ambient pressure drying and photocatalytic performance. Ceram. Int., 40: 13781-13786.

DOI: 10.1016/j.ceramint.2014.05.093

Crick, C.R., C.B. Joseph, K. Andreas and L.P. Parkin, 2012. Super-hydrophobic photocatalytic surfaces through direct incorporation of titania nanoparticles into a polymer matrix by aerosol assisted chemical vapor deposition. Adv. Mater., 24: 3505-3508.

DOI: $10.1002 / \mathrm{adma} .201201239$

Dai, X., B.S. Birgitt, Y. Shikuan and T.S. Wonget, 2015. Slippery wenzel state. ACS Nano, 9: 9260-9267. DOI: $10.1021 /$ acsnano.5b04151

Darmanin, T. and F. Guittard, 2015. Super-hydrophobic and superoleophobic properties in nature. Mater. Today, 18: 273-285.

DOI: $10.1016 /$ j.mattod.2015.01.001

Dunderdale, G.J., U. Chihiro, S. Tomoya, W.E. Ngland and H. Atsushi, 2015. Continuous, High-Speed and Efficient Oil/Water Separation using Meshes with Antagonistic Wetting Properties. ACS Applied Mater. Interfaces, 7: 18915-18919.

DOI: $10.1021 /$ acsami.5b06207

Emeline, A.V., V.R. Aida, S. Munetoshi, M. Taketoshi and F. Akira, 2013. Factors affecting UV-induced super hydrophilic conversion of a $\mathrm{TiO}_{2}$ surface. J. Phys. Chem. C, 117: 12086-12092.

DOI: $10.1021 / j p 400421 \mathrm{v}$

Erdural, B., U. Bolukbasi and G. Karakas, 2014. Photocatalytic antibacterial activity of $\mathrm{TiO}_{2}-\mathrm{SiO}_{2}$ thin films: the effect of composition on cell adhesion and antibacterial activity. J. Photochem. Photobiol., A: Chem., 283: 29-37.

DOI: $10.1016 /$ j.jphotochem.2014.03.016
Etacheri, V., M. Georg, K.S. Michael, J.H. Steven and C.P. Suresh, 2013. A Highly Efficient $\mathrm{TiO}_{2-\mathrm{x}} \mathrm{C}_{\mathrm{x}}$ Nano-heterojunction Photo-catalyst for Visible Light Induced Antibacterial Applications. ACS Applied Mater. Interfaces, 5: 1663-1672. DOI: 10.1021/am302676a

Fateh, R., R. Dillert and D. Bahnemann, 2014. SelfCleaning properties, mechanical stability and adhesion strength of transparent photocatalytic $\mathrm{TiO}_{2}-\mathrm{ZnO}$ coatings on polycarbonate. ACS Applied Mater. interfaces, 6: 2270-2278.

DOI: $10.1021 / \mathrm{am} 4051876$

Feng, N., W. Qiang, Z. Anmin, Z. Zhengfeng and F. Jie, 2013. Understanding the high photocatalytic activity of $(\mathrm{B}, \mathrm{Ag})$-codoped $\mathrm{TiO}_{2}$ under solar-light irradiation with XPS, solid-state NMR and DFT calculations. J. Am. Chem. Society, 135: 1607-1616. DOI: $10.1021 /$ ja312205c

Fillion, R., A. Riahi and A. Edrisy, 2014. A review of icing prevention in photovoltaic devices by surface engineering. Renewable Sustainable Energy Rev., 32: 797-809. DOI: 10.1016/j.rser.2014.01.015

Fisher, M.B., A.K. Donal, F.I. Pilar, C. John and J.H. Steven, 2013. Nitrogen and copper doped solar light active $\mathrm{TiO}_{2}$ photo catalysts for water decontamination. Applied Catalysis B: Environ., 130: 8-13. DOI: 10.1016/j.apcatb.2012.10.013

Galkina, O.L., A. Sychevac, A. Blagodatskiy, G. Kaptay and V.L. Katanaev et al., 2014. The sol-gel synthesis of cotton/ $/ \mathrm{TiO}_{2}$ composites and their antibacterial properties. Surface Coatings Technol., 253: 171-179. DOI: 10.1016/j.surfcoat.2014.05.033

Gao, S.J., S. Zhun, W.B. Zhang, Z. Feng and J. Jian, 2014a. Photo-induced super wetting single-walled carbon nanotube $/ \mathrm{TiO}_{2}$ ultrathin network films for ultrafast separation of oil-in-water emulsions. ACS Nano, 8: 6344-6352. DOI: 10.1021/nn501851a

Gao, P., L. Zhaoyang, D.S. Darren and J.N. Wun, 2014b. The efficient separation of surfactant-stabilized oilwater emulsions with a flexible and super hydrophilic graphene- $\mathrm{TiO}_{2}$ composite membrane. J. Mater. Chem. A, 2: 14082-14088.

DOI: $10.1039 / \mathrm{C} 4 \mathrm{TA02039A}$

George, S.D., L. Uma, T. John, B. Aseefhali and C. Santhosh et al., 2014. Deposition and alignment of cells on laser-patterned quartz. Applied Surface Sci., 305: 375-381. DOI: 10.1016/j.apsusc.2014.03.095

Guldin, S., K. Peter, S. Morgan, S. Juho and D. Giorgio, 2013. Self-cleaning antireflective optical coatings. Nano Lett., 13: 5329-5335. DOI: 10.1021/nl402832u

Gurav, A.B., S.L. Sanjay, S.V. Rajiv, J.G. Lee and D.Y. Kim et al., 2014. Super hydrophobic surface decorated with vertical $\mathrm{ZnO}$ Nano rods modified by stearic acid. Ceram. Int., 40: 7151-7160. DOI: 10.1016/j.ceramint.2013.12.052 
Gurav, A.B., X. Qingfeng, S.L. Sanjay, R.S.Vhatkar and L. Shanhu et al., 2015. Super hydrophobic coatings prepared from methyl-modified silica particles using simple dip-coating method. Ceram. Int., 41: 3017-3023. DOI: 10.1016/j.ceramint.2014.10.137

Hamilton, J.W., J.A. Byrneet, S.M.D. Patrick, D.D. Dionysios and P. Miguel, 2014. Evaluating the mechanism of visible light activity for $\mathrm{N}, \mathrm{F}-\mathrm{TiO}_{2}$ using photo electrochemistry. J. Phys. Chem. C, 118: 12206-12215. DOI: 10.1021/jp4120964

Hancock, M.J., K. Sekeroglu and M.C. Demirel, 2012. Bioinspired directional surfaces for adhesion, wetting and transport. Adv. Funct. Mater., 22: 2223-2234. DOI: 10.1002/adfm.201103017

Kamei, J., Y. Saito and H. Yabu, 2014. Biomimetic ultra-bubble-repellent surfaces based on a selforganized honeycomb film. Langmuir, 30: 14118-14122. DOI: 10.1021/la5035454

Kapridaki, C., P. Luís, J.M. Maria and M.K. Pagona, 2014. Producing photoactive, transparent and hydrophobic $\mathrm{SiO}_{2}$-crystalline $\mathrm{TiO}_{2}$ nanocomposites at ambient conditions with application as selfcleaning coatings. Applied Catalysis B: Environ., 156: 416-427. DOI: 10.1016/j.apcatb.2014.03.042

Karimi, L., M.E. Yazdanshenas, K. Ramin, R. Abosaeed and M. Mirjalili, 2014a. Using graphene/ $/ \mathrm{TiO}_{2}$ nanocomposite as a new route for preparation of electro conductive, self-cleaning, antibacterial and antifungal cotton fabric without toxicity. Cellulose, 21: 3813-3827.

Karimi, L., S. Zohoori and A. Amini, 2014b. Multi-wall carbon nanotubes and nano titanium dioxide coated on cotton fabric for superior self-cleaning and UV blocking. New Carbon Mater., 29: 380-385. DOI: 10.1016/S1872-5805(14)60144-X

Katsanaki, A.V., G.K. Athanassios, M. Thomas, P. Miguel and L. Vlassis, 2013. Photocatalytic oxidation of nitrogen oxides on N-F-doped titania thin films. Applied Catalysis B: Environ., 140: 619-625. DOI: $10.1016 /$ j.apcatb.2013.04.070

Ke, S., C. Xiaosu, W. Qianghong, W. Yanmin and P. Zhidong, 2014. Preparation of a photocatalytic $\mathrm{TiO}_{2} / \mathrm{ZnTiO}_{3}$ coating on glazed ceramic tiles. Ceram. Int., 40: 8891-8895.

DOI: 10.1016/j.ceramint.2014.01.027

Keane, D.A., G.M. Kevin, F.I. Pilar, M.I. Polo-López and J.A. Byrne, 2014. Solar photo catalysis for water disinfection: materials and reactor design. Catalysis Sci. Technol., 4: 1211-1226.

DOI: $10.1039 / C 4 C Y 00006 D$

Kim, S.M., I. In and S.Y. Park, 2016. Study of photoinduced hydrophilicity and self-cleaning property of glass surfaces immobilized with $\mathrm{TiO}_{2}$ nanoparticles using catechol chemistry. Surface Coat. Technol., 294: 75-82. DOI: 10.1016/j.surfcoat.2016.03.080
Kisch, H., 2013. Semiconductor photo catalysismechanistic and synthetic aspects. Angewandte Chem. Int. Edit., 52: 812-847. DOI: 10.1002/anie.201201200

Kitano, S., M. Naoya, O. Teruhisa, M. Yasufumi and N. Yoshio, 2013. Bifunctionality of $\mathrm{Rh}^{3+}$ modifier on $\mathrm{TiO}_{2}$ and working mechanism of $\mathrm{Rh}^{3+/} \mathrm{TiO}_{2}$ photo catalyst under irradiation of visible light. J. Phys. Chem. C, 117: 11008-11016.

DOI: $10.1021 /$ jp311801e

Lai, Y., L. Longxiang, P. Fei, H. Jianying and S. Ran, 2013. Nanotube arrays: Bioinspired patterning with extreme wettability contrast on $\mathrm{TiO}_{2}$ nanotube array surface: A versatile platform for biomedical applications (Small 17/2013). Small, 9: 3004-3004. DOI: $10.1002 / \mathrm{smll} .201370100$

Lee, K.S., I. In and S.Y. Park, 2014. pH and redox responsive polymer for antifouling surface coating. Applied Surface Sci., 313: 532-536.

DOI: $10.1016 /$ j.apsusc.2014.06.017

Lei, Y., Q. Wang and J. Huo, 2014. Fabrication of durable super hydrophobic coatings with hierarchical structure on inorganic radome materials. Ceram. Int., 40: 10907-10914. DOI: $10.1016 /$ j.ceramint.2014.03.087

Li, H., C. Qiangal, F. Bo, W. Jianxin and L. Xiong et al., 2013a. Antibacterial activity of $\mathrm{TiO}_{2}$ nanotubes: Influence of crystal phase, morphology and $\mathrm{Ag}$ deposition. Applied Surface Sci., 284: 179-183. DOI: 10.1016/j.apsusc.2013.07.076

Li, K., Z. Xingrong, L. Hongqiang and L. Xuejun, 2015c. A study on the fabrication of super hydrophobic iron surfaces by chemical etching and galvanic replacement methods and their anti-icing properties. Applied Surface Sci., 346: 458-463. DOI: 10.1016/j.apsusc.2015.03.130

Li, W., G. Ting, M. Tao, H. Yushi and L. Xing, 2013b. Enhanced reversible wettability conversion of micro-nano hierarchical $\mathrm{TiO}_{2} / \mathrm{SiO}_{2}$ composite films under UV irradiation. Applied Surface Sci., 283: 12-18. DOI: 10.1016/j.apsusc.2013.05.085

$\mathrm{Li}, \mathrm{X}$. and J. He, 2013. Synthesis of raspberry-like $\mathrm{SiO}_{2}-$ $\mathrm{TiO}_{2}$ nanoparticles toward antireflective and selfcleaning coatings. ACS Applied materials interfaces, 5: 5282-5290. DOI: 10.1021/am401124j

Li, X., L. Pengwei, M. Yu, X. Mingyang and Z. Jinlong, 2015a. Preparation of homogeneous nitrogen-doped mesoporous $\mathrm{TiO}_{2}$ spheres with enhanced visible-light photo catalysis. Applied Catalysis B: Environ., 164: 352-359. DOI: $10.1016 /$ j.apcatb.2014.09.053

Li, Y., Z. Haichuan, X. Tianhao, L. Zhiyi and W. Xiaochao et al., 2015b. Under-Water Superaerophobic Pine-Shaped Pt Nanoarray Electrode for Ultrahigh-Performance Hydrogen Evolution. Advanced Functional Materials, 25: 1737-1744. DOI: $10.1002 / \mathrm{adfm} .201404250$ 
Lien, S.y., N. Asheesh, J.H. Jhu and S.J. Lee, 2013. Surface Chemistry of Super-Hydrophilic $\mathrm{SiO}_{2}-$ Doped $\mathrm{TiO}_{2}$ Photo-Catalysts for Self-Cleaning Glass. Asian J. Chem., 25: 6071-6074.

Liu, G., C. Han, P. Miguel, Z. Duanwei and L. Shuijiao, 2013b. Enhanced visible light photocatalytic activity of $\mathrm{CN}$-codoped $\mathrm{TiO}_{2}$ films for the degradation of microcystin-LR. J. Molecular Catalysis A: Chem., 372: 58-65. DOI: 10.1016/j.molcata.2013.02.006

Liu, K., C. Moyuan, F. Akira and J. Lei, 2014a. Bioinspired titanium dioxide materials with special wettability and their applications. Chem. Rev., 114: 10044-10094. DOI: $10.1021 / \mathrm{cr} 4006796$

Liu, K., Y. Tian and L. Jiang, 2013a. Bio-inspired superoleophobic and smart materials: design, fabrication and application. Progress Mater. Sci., 58: 503-564. DOI: 10.1016/j.pmatsci.2012.11.001

Liu, Y., M. Lisa, X. Xinpeng, Q. Tiezheng and M.Y. Julia et al., 2014b. Pancake bouncing on super hydrophobic surfaces. Nature Phys., 10: 515-519. DOI:10.1038/nphys2980

Lochovsky, C., S. Yasotharan and A. Günther, 2012. Bubbles no more: in-plane trapping and removal of bubbles in microfluidic devices. Lab Chip, 12: 595-601. DOI: 10.1039/C1LC20817A

Long, J., F. Peixun, G. Dingwei, J. Dafa and Z. Hongjun et al., 2015. Super hydrophobic surfaces fabricated by femtosecond laser with tunable water adhesion: From lotus leaf to rose petal. ACS Applied Mater. Interfaces, 7: 9858-9865. DOI: $10.1021 /$ acsami.5b01870

Lu, Y., S. Sanjayan, S. Jinlong, R.C. Colin and J.C. Claire, 2015. Robust self-cleaning surfaces that function when exposed to either air or oil. Science, 347: 1132-1135. DOI: 10.1126/science.aaa0946

Lu, Z., S. Ming, X. Tianhao, L. Yingjie and X. Wenwen et al., 2015. Superaerophobic electrodes for direct hydrazine fuel cells. Adv. Mater., 27: 2361-2366. DOI: 10.1002/adma.201500064

Lv, P., X. Yahui, S. Yipeng, L. Hao and D. Huiling, 2014. Metastable states and wetting transition of submerged super hydrophobic structures. Phys. Rev. Lett., 112: 196101-196101. DOI: 10.1103/PhysRevLett.112.196101

Manabe, K., N. Shingo, K.H. Kyung and S. Seimei, 2014. Optical phenomena and antifrosting property on biomimetics slippery fluid-infused antireflective films via layer-by-layer comparison with super hydrophobic and antireflective films. ACS Applied Mater. Interfaces, 6: 13985-13993.

DOI: $10.1021 / \mathrm{am} 503352 \mathrm{x}$

Midtdal, K. and B.P. Jelle, 2013. Self-cleaning glazing products: A state-of-the-art review and future research pathways. Solar Energy Mater. Solar Cells, 109: 126-141. DOI: 10.1016/j.solmat.2012.09.034
Miljkovic, N., J.P. Daniel, E. Ryan and N.W. Evelyn, 2013. Electrostatic charging of jumping droplets. Nature Commun., 4: 2517-2517.

DOI: $10.1038 /$ ncomms 3517

Mills, A., C. Hill and P.K. Robertson, 2012. Overview of the current ISO tests for photocatalytic materials. J. Photochem. Photobiol. A: Chem., 237: 7-23. DOI: 10.1016/j.jphotochem.2012.02.024

Mills, A., H. James, H. David, O.R. Christopher and K. Josef et al., 2013. A simple, inexpensive method for the rapid testing of the photocatalytic activity of self-cleaning surfaces. J. Photochem. Photobiol. A: Chem., 272: 18-20.

DOI: $10.1016 /$ j.jphotochem.2013.08.004

Mills, A., H. James, H. David, O.R. Christopher, W. Nathan et al., 2014a. Photocatalytic activity indicator inks for probing a wide range of surfaces. J. Photochem. Photobiol. A: Chem., 290: 63-71. DOI: $10.1016 /$ j.jphotochem.2014.06.007

Mills, A., N. Wells and C. O'Rourke, 2014b. Correlation between $\triangle \mathrm{Abs}, \triangle \mathrm{RGB}$ (red) and stearic acid destruction rates using commercial self-cleaning glass as the photocatalyst. Catalysis Today, 230: 245-249. DOI: 10.1016/j.cattod.2013.11.023

Mokhtarimehr, M., M. Pakshira, E. Akbar and M.H. Shariata, 2013. Super-hydrophilic property of vanadium doped $\mathrm{TiO}_{2}-\mathrm{SiO}_{2}$ sol-gel derived thin film. Thin Solid Films, 532: 123-126.

DOI: $10.1016 /$ j.tsf.2012.12.104

Montazer, M., A. Behzadnia and M.B. Moghadam, 2012. Superior self-cleaning features on wool fabric using $\mathrm{TiO}_{2} / \mathrm{Ag}$ nanocomposite optimized by response surface methodology. J. Applied Polymer Sci., 125: E356-E363. DOI: 10.1002/app.36768

Murakami, D., H. Jinnai and A. Takahara, 2014. Wetting transition from the Cassie-Baxter state to the Wenzel state on textured polymer surfaces. Langmuir, 30: 2061-2067. DOI: 10.1021/la4049067

Murugan, K., R. Subasri, T.N. Rao, S.G. Ashutosh and B.S. Murty, 2013. Synthesis, characterization and demonstration of self-cleaning $\mathrm{TiO}_{2}$ coatings on glass and glazed ceramic tiles. Progress Organic Coat., 76: 1756-1760.

DOI: $10.1016 /$ j.porgcoat.2013.05.012

Nakata, K., C. Terashima and A. Fujishima, 2014. Motheye-structured Antireflective Poly(methyl methacrylate) Film with Visible-light-responsive Self-cleaning Ability. Chem. Lett., 43: 1511-1513. DOI: $10.1246 / \mathrm{cl} .140546$

Nam, J.A., N. Abdullah-Al, M.K. Sung, I. Insik and Y.P. Sung, 2013. Successful stabilization of functionalized hybrid graphene for highperformance antimicrobial activity. Acta Biomater., 9: 7996-8003. DOI: 10.1016/j.actbio.2013.04.022 
Nandan, S., T.G. Deepak, V.N. Shantikumar and A.S. Nair, 2015. $\mathrm{TiO}_{2}$ nanofibers resembling 'yellow bristle grass' in morphology by a soft chemical transformation. Dalton Trans., 44: 9637-9645. DOI: $10.1039 / \mathrm{C} 5 \mathrm{DT} 01027 \mathrm{~F}$

Nawaz, M., K. Dongwoo, M. Waheed, K. Avinash and H. Jun et al., 2015. Effect of toluene, an immiscible pollutant, on the photocatalytic degradation of azo dye. J. Industrial Eng. Chem., 30: 10-13.

DOI: $10.1016 /$ j.jiec.2015.05.010

Nishimoto, S. and B. Bhushan, 2013. Bioinspired selfcleaning surfaces with super hydrophobicity, superoleophobicity and super hydrophilicity. RSC. Adv., 3: 671-690.

DOI: $10.1039 / \mathrm{C} 2 \mathrm{RA} 21260 \mathrm{~A}$

Niu, Y., X. Mingyang, Z. Jinlong and T. Baozhu, 2013. Visible light activated sulfur and iron co-doped $\mathrm{TiO}_{2}$ photo catalyst for the photocatalytic degradation of phenol. Catalysis Today, 201: 159-166. DOI: $10.1016 /$ j.cattod.2012.04.035

Oberli, L., C. Dean, H. Colin, F. Manrico and J.M. Peter, 2014. Condensation and freezing of droplets on super hydrophobic surfaces. Adv. Colloid Interface sci., 210: 47-57. DOI: 10.1016/j.cis.2013.10.018

Pakdel, E. and W.A. Daoud, 2013. Self-cleaning cotton functionalized with $\mathrm{TiO}_{2} / \mathrm{SiO}_{2}$ : Focus on the role of silica. J. Colloid Interface Sci., 401: 1-7.

DOI: $10.1016 /$ j.jcis.2013.03.016

Pakdel, E., W.A. Daoud and X. Wang, 2013. Selfcleaning and super hydrophilic wool by $\mathrm{TiO}_{2} / \mathrm{SiO}_{2}$ nanocomposite. Applied Surface sci., 275: 397-402. DOI: 10.1016/j.apsusc.2012.10.141

Pasqui, D. and R. Barbucci, 2014. Synthesis, characterization and self cleaning properties of titania nanoparticles grafted on polyester fabrics. J. Photochemistry Photobiol. A: Chem., 274: 1-6. DOI: $10.1016 /$ j.jphotochem.2013.08.017

Patrocinio, A.O.T., F.P. Leonardo, M.P. Roberto, F. Janna and W.B. Detlef, 2014. Layer-by-Layer $\mathrm{TiO}_{2} / \mathrm{WO}_{3}$ thin films as efficient photocatalytic selfcleaning surfaces. ACS Applied Mater. Interfaces, 6: 16859-16866. DOI: 10.1021/am504269a

Pelaez, M., F. Polycarpos, G.K. Athanassios, A.D.LC. Armah and O. Kevin, 2012. A comparative study on the removal of cylindrospermopsin and microsystems from water with $\mathrm{NF}^{-\mathrm{TiO}_{2}}-\mathrm{P} 25$ composite films with visible and UV-vis light photocatalytic activity. Applied Catalysis B: Environ., 121: 30-39.

DOI: 10.1016/j.apcatb.2012.03.010

Qu, Y. and X. Duan, 2013. Progress, challenge and perspective of heterogeneous photo catalysts. Chem. Society Rev., 42: 2568-2580.

DOI: $10.1039 / \mathrm{C} 2 \mathrm{CS} 35355 \mathrm{E}$
Radeka, M., S. Markov, E. Lončar, O. Rudić and S.Vučetić et al., 2014. Photocatalytic effects of $\mathrm{TiO}_{2}$ mesoporous coating immobilized on clay roofing tiles. J. Eur. Ceramic Society, 34: 127-136. DOI: 10.1016/j.jeurceramsoc.2013.07.010

Radetić, M., 2013. Functionalization of textile materials with $\mathrm{TiO}_{2}$ nanoparticles. J. Photochem. Photobiol. C: Photochem. Rev., 16: 62-76. DOI: 10.1016/j.jphotochemrev.2013.04.002

Ragesh, P., V.A. Ganesh, V.N. Shantikumar and A.S. Nair, 2014. A review on 'self-cleaning and multifunctional materials. J. Mater. Chem. A, 2: 14773-14797. DOI: 10.1039/C4TA02542C

Raza, M.A., H.J.W. Zandvliet, B. Poelsema and E.S. Kooij, 2015. Hydrophobic surfaces with tunable dynamic wetting properties via colloidal assembly of silica microspheres and gold nanoparticles. J. SolGel Sci. Technol., 74: 357-367. DOI: 10.1007/s10971-014-3476-4

Rehan, M., H. Andreas, O. Matthias, G. Linda and W. Ralph, 2013. Enhancement of photocatalytic selfcleaning activity and antimicrobial properties of poly(ethylene terephthalate) fabrics. Surface Coat. Technol., 219: 50-58.

DOI: $10.1016 /$ j.surfcoat.2013.01.003

Reszczyńska, J., G. Tomasz, W.S. Janusz, L. Wojciech and G. Maria, 2015. Visible light activity of rare earth metal doped $\left(\mathrm{Er}^{3+}, \mathrm{Yb}^{3+}\right.$ or $\left.\mathrm{Er}^{3+} / \mathrm{Yb}^{3+}\right)$ titania photo catalysts. Applied Catalysis B: Environ., 163: 40-49. DOI: 10.1016/j.apcatb.2014.07.010

Sakai, N., F. Akira, W. Toshiya and H. Kazuhito, 2003. Quantitative evaluation of the photo induced hydrophilic conversion properties of $\mathrm{TiO}_{2}$ thin film surfaces by the reciprocal of contact angle. J. Phys. Chem. B, 107: 1028-1035. DOI: 10.1021/jp022105p

Sawai, Y., N. Shunsuke, K. Yoshikazu, F. Eiji and M. Michihiro, 2013. Photo induced underwater superoleophobicity of $\mathrm{TiO}_{2}$ thin films. Langmuir, 29: 6784-6789. DOI: 10.1021/la401382g

Shang, Q. and Y. Zhou, 2015. Facile fabrication of hollow mesoporous silica microspheres with hierarchical shell structure via a sol-gel process. J. Sol-Gel Sci. Technol., 75: 206-214.

Sharker, S.M., M.K. Sung, E.L. Jung, H.C. Kyung and S. Gyojic et al., 2015. Functionalized biocompatible $\mathrm{WO}_{3}$ nanoparticles for triggered and targeted in vitro and in vivo photo thermal therapy. J. Controlled Release, 217: 211-220. DOI: $10.1016 /$ j.jconrel.2015.09.010

Shi, C., C. Xin, X. Lei, L. Qingxia and Y.C.C. Derek et al., 2014a. Measuring forces and spatiotemporal evolution of thin water films between an air bubble and solid surfaces of different hydrophobicity. ACS Nano, 9: 95-104.

DOI: $10.1021 / \mathrm{nn} 506601 \mathrm{j}$ 
Shi, C., Y.C.C. Derek, L. Qingxia and Z. Hongbo, 2014b. Probing the hydrophobic interaction between air bubbles and partially hydrophobic surfaces using atomic force microscopy. J. Phys. Chem. C, 118: 25000-25008. DOI: $10.1021 / \mathrm{jp} 507164 \mathrm{c}$

Shi, C., C. Xin, Z. Xurui, T. Plamen and L. Qingxia et al., 2015. Interaction between air bubbles and superhydrophobic surfaces in aqueous solutions. Langmuir, 31: 7317-7327.

DOI: 10.1021/acs.langmuir.5b01157

Song, W. and J.F. Mano, 2013. Interactions between cells or proteins and surfaces exhibiting extreme wettabilities. Soft Matter, 9: 2985-2999.

DOI: $10.1039 / \mathrm{C} 3 \mathrm{SM} 27739 \mathrm{~A}$

Spasiano, D., M. Raffaele, M. Sixto, F.I. Pilar and D.S. Ilaria, 2015. Solar photo-catalysis: materials, reactors, some commercial and pre-industrialized applications. A comprehensive approach. Applied Catalysis B: Environ., 170: 90-123.

DOI: $10.1016 /$ j.apcatb.2014.12.050

Tian, D., Y. Song and L. Jiang, 2013a. Patterning of controllable surface wettability for printing techniques. Chem. Society Rev., 42: 5184-5209. DOI: $10.1039 / \mathrm{C} 3 \mathrm{CS} 35501 \mathrm{~B}$

Tian, G., C. Yajie, Z. Rutao, Z. Juan and Z. Wei, 2013b. Hierarchical flake-like $\mathrm{Bi}_{2} \mathrm{MoO}_{6} / \mathrm{TiO}_{2}$ bilayer films for visible-light-induced self-cleaning applications. J. Mater. Chem. A, 1: 6961-6968. DOI: $10.1039 / \mathrm{C} 3 \mathrm{TA} 10511 \mathrm{C}$

Ueda, E. and P.A. Levkin, 2013. Emerging applications of superhydrophilic-superhydrophobic micropatterns. Adv. Mater., 25: 1234-1247. DOI: $10.1002 /$ adma.201204120

Vorobyev, A. and C. Guo, 2015. Multifunctional surfaces produced by femtosecond laser pulses. J. Applied Phys., 117: 033103-033103. DOI: 10.1063/1.4905616

Wang, D., 2014. Mater. Chem. A.

Wang, H. and Z. Guo, 2014. Design of underwater superoleophobic $\mathrm{TiO}_{2}$ coatings with additional photoinduced self-cleaning properties by one-step route bioinspired from fish scales. Applied Phys. Lett., 104: 183703-183703. DOI: 10.1063/1.4876116

Wang, H., Z. Hua, N. Haitao, Z. Jin and D. Yong et al., 2015. Dual-Layer Superamphiphobic/Superhydrophobic-oleophilic nanofibrous membranes with unidirectional oil-transport ability and strengthened oil-water separation performance. Adv. Mater. Interfaces, 2: 1400506-1400506. DOI: 10.1002/admi.201400506

Wang, J., C. Lu and J. Xiong, 2014a. Self-cleaning and depollution of fiber reinforced cement materials modified by neutral $\mathrm{TiO}_{2} / \mathrm{SiO}_{2}$ hydrosol photoactive coatings. Applied Surface Sci., 298: 19-25.

DOI: $10.1016 /$ j.apsusc.2013.12.171
Wang, L., K.P. Anoop, A.I. Jacqueline, B. Dhimiter, L.C. Rebecca, 2014b. Nanomaterial induction of oxidative stress in lung epithelial cells and macrophages. J. Nanoparticle Res., 16: 1-14.

DOI: $10.1007 \% 2 F s 11051-014-2591-z$

Wang, T., C. Lijing, Y. Sen, J. Yang and W. Chingping, 2013. Hydrophobic properties of biomorphic carbon surfaces prepared by sintering lotus leaves. Ceram. Int., 39: 8165-8172.

DOI: $10.1016 /$ j.ceramint.2013.03.092

Weng, K.W. and Y.P. Huang, 2013. Preparation of $\mathrm{TiO}_{2}$ thin films on glass surfaces with selfcleaning characteristics for solar concentrators. Surface Coat. Technol., 231: 201-204. DOI: 10.1016/j.surfcoat.2012.06.058

Wooh, S., H.K. Jai, L. Soojin, Y. Hyunsik and C. Kookheon, 2014. Trilevel-structured superhydrophobic pillar arrays with tunable optical functions. Adv. Funct. Mater., 24: 5550-5556. DOI: $10.1002 /$ adfm.201400228

Wu, S.H., W. Jing-Long, J. Shao-Yi, C. Qiao-Wan and R. Hai-Tao, 2013b. Cobalt(II) phthalocyaninesensitized hollow $\mathrm{Fe}_{3} \mathrm{O}_{4} @ \mathrm{SiO}_{2} @ \mathrm{TiO}_{2}$ hierarchical nanostructures: Fabrication and enhanced photocatalytic properties. Applied Surface Sci., 287: 389-396.

DOI: $10.1016 /$ j.apsusc.2013.09.164

Wu, X., Y. Shu, D. Qiang, G. Chongshen and K. Takeshi, 2013a. Photocatalytic properties of Nd and C codoped $\mathrm{TiO}_{2}$ with the whole range of visible light absorption. J. Phys. Chem. C, 117: 8345-8352. DOI: $10.1021 / j p 402063 n$

Xiao, S., Z. Lei, L. Xuning, L. Xingyou and L. Jianshe, 2014. Synthesis of amorphous $\mathrm{TiO}_{2}$ modified $\mathrm{ZnO}$ nanorod film with enhanced photocatalytic properties. Applied Surface Sci., 299: 97-104.

DOI: 10.1016/j.apsusc.2014.01.192

Xie, Y., J. Yanyan, Z. Yingzhi and W. Yong, 2014. SERS activity of self-cleaning silver/titania nanoarray. Applied Surface Sci., 313: 549-557. DOI: 10.1016/j.apsusc.2014.06.020

Xu, Q.F., L. Yang, L. Fang-Ju, M. Bikash and M.L. Alan, 2013b. Super hydrophobic $\mathrm{TiO}_{2}$-polymer nanocomposite surface with $\mathrm{UV}$-induced reversible wettability and self-cleaning properties. ACS Applied Mater. Interfaces, 5: 8915-8924. DOI: 10.1021/am401668y

Xu, S.C., Y.X. Zhang, Y.Y. Luo, S. Wang and H.L. Ding, 2013c. Ag-decorated $\mathrm{TiO}_{2}$ nanograss for 3D SERS-active substrate with visible light selfcleaning and reactivation. Analyst, 138: 4519-4525. DOI: $10.1039 / \mathrm{C} 3 \mathrm{AN} 00750 \mathrm{~B}$ 
Xu, Y.J., J.X. Liaoa, Q.W. Caib and X.X. Yang, 2013a. Preparation of a highly-reflective $\mathrm{TiO}_{2} / \mathrm{SiO}_{2} / \mathrm{Ag}$ thin film with self-cleaning properties by magnetron sputtering for solar front reflectors. Solar Energy Mater. Solar Cells, 113: 7-12.

DOI: 10.1016/j.solmat.2013.01.034

Yadav, H.M., V.O. Sachin, A.B. Raghvendra, S.M. Sawanta and H.P. Shivaji, 2014. Synthesis and visible light photocatalytic antibacterial activity of nickel-doped $\mathrm{TiO}_{2}$ nanoparticles against Grampositive and Gram-negative bacteria. J. Photochem. Photobiol. A: Chem., 294: 130-136.

DOI: 10.1016/j.jphotochem.2014.07.024

Yang, H.I., L. Sheng-Nan, L. Yun-Fan, Y. San-Lin and S. Chien-An, 2002. Hepatitis B e antigen and the risk of hepatocellular carcinoma. New England J. Med., 347: 168-174. DOI: 10.1056/NEJMoa013215

Yao, L. and J. He, 2014. Recent progress in antireflection and self-cleaning technology - From surface engineering to functional surfaces. Progress Mater. Sci., 61: 94-143.

DOI: $10.1016 /$ j.pmatsci.2013.12.003

Yao, X., Y. Song and L. Jiang, 2011. Applications of bio-inspired special wettable surfaces. Adv. Mater., 23: 719-734. DOI: 10.1002/adma.201002689

Yong, J., C. Feng, Y. Qing and H. Xun, 2015. Femtosecond laser controlled wettability of solid surfaces. Soft Matter, 11: 8897-8906.

DOI: $10.1039 / \mathrm{C} 5 \mathrm{SM} 02153 \mathrm{G}$

Yong, J., C. Feng, Y. Qing, Z. Dongshi and D. Guangqing et al., 2013. Femtosecond laser weaving super hydrophobic patterned PDMS surfaces with tunable adhesion. J. Phys. Chem. C, 117: 24907-24912. DOI: 10.1021/jp408863u

Yong, J., Y. Qing, C. Feng, Z. Dongshi and F. Umar, 2014. A simple way to achieve super hydrophobicity, controllable water adhesion, anisotropic sliding and anisotropic wetting based on femtosecond-laser-induced line-patterned surfaces. J. Mater. Chem. A, 2: 5499-5507.

DOI: $10.1039 / \mathrm{C} 3 \mathrm{TA} 14711 \mathrm{H}$

Zang, Y., Y. Jun, H. Xu, Y. Chuang and W. Zhiming et al., 2014. Plasmonic-enhanced self-cleaning activity on asymmetric $\mathrm{Ag} / \mathrm{ZnO}$ surface-enhanced Raman scattering substrates under UV and visible light irradiation. J. Mater. Chem. A, 2: 7747-7753.

DOI: $10.1039 / \mathrm{C} 4 \mathrm{TA} 00824 \mathrm{C}$

Zhang, E., W. Youshan, L. Tong, L. Li and C. Zhongjun et al., 2015b. Bio-inspired design of hierarchical PDMS microstructures with tunable adhesive super hydrophobicity. Nanoscale, 7: 6151-6158.

DOI: $10.1039 / \mathrm{C} 5 \mathrm{NR} 00356 \mathrm{C}$
Zhang, L., D. Ralf, B. Detlef and V. Michaela, 2012. Photo-induced hydrophilicity and self-cleaning: Models and reality. Energy Environ. Sci., 5: 7491-7507. DOI: 10.1039/C2EE03390A

Zhang, P., T. Jie, X. Ruifen and M. Guojun, 2013b. Hydrophilicity, photocatalytic activity and stability of tetraethyl orthosilicate modified $\mathrm{TiO}_{2}$ film on glazed ceramic surface. Applied Surface Sci., 266: 141-147. DOI: 10.1016/j.apsusc.2012.11.117

Zhang, X., G. Yonggang, Z. Zhijun and Z. Pingyu, 2013a. Self-cleaning super hydrophobic surface based on titanium dioxide nanowires combined with polydimethylsiloxane. Applied Surface Sci., 284: 319-323. DOI: 10.1016/j.apsusc.2013.07.100

Zhang, Y., Z. Zhiyuan, C. Juanrong, C. Li and C. Jun, 2015a. Corrigendum to "C-doped hollow $\mathrm{TiO}_{2}$ spheres: In situ synthesis, controlled shell thickness and superior visible-light photocatalytic activity" [Appl. Catal. B: Environ. 165 (2015) 715-722]. Applied Catalysis B: Environ., 166: 644-644. DOI: $10.1016 /$ j.apcatb.2014.11.054

Zhao, N., W. Zhen, C. Chao, S. Heng and L. Feiyue, 2014. Bioinspired materials: from low to high dimensional structure. Adv. Mater., 26: 6994-7017. DOI: 10.1002/adma.201401718

Zhao, Z., T. Huaqiao, Z. Haifeng, L. Di and Z. Min, 2013. Orientated anatase $\mathrm{TiO}_{2}$ nanocrystal array thin films for self-cleaning coating. Chem. Commun., 49: 8958-8960. DOI: 10.1039/C3CC44547J

Zhou, Y., L. Mengyao, Z. Xian, Z. Zhiping and D. Pan et al., 2015. Hydrophobic composite coatings with photocatalytic self-cleaning properties by micro/nanoparticles mixed with fluorocarbon resin. Ceram. Int., 41: 5341-5347. DOI: 10.1016/j.ceramint.2014.12.090

Zhu, J., Y. Cao and J. He, 2014. Facile fabrication of transparent, broadband photo response, self-cleaning multifunctional graphene- $\mathrm{TiO}_{2}$ hybrid films. J. Colloid Interface Sci., 420: 119-126. DOI: $10.1016 /$ j.jcis.2014.01.015 